\title{
Distribution and biological implications of plastic pollution on the fringing reef of Mo'orea, French Polynesia
}

Elizabeth J Connors Corresp. 1

1 Marine Science and Integrative Biology, University of California, Berkeley, Berkeley, California, United States
Corresponding Author: Elizabeth J Connors
Email address: bethconnors@berkeley.edu

Coral reef ecosystems of the South Pacific are extremely vulnerable to plastic pollution from oceanic gyres and land-based sources. To describe the extent and impact of plastic pollution, the distribution of both macro- $(>5 \mathrm{~mm})$ and microplastic (plastic $<5 \mathrm{~mm}$ ) of the fringing reef of an isolated South Pacific island, Mo'orea, French Polynesia was quantified. Macroplastic was found on every beach on the island that was surveyed. The distribution of this plastic was categorized by site type and by the presence of Turbinaria ornata, a common macroalgae on Mo'orea. Microplastics were discovered in the water column of the fringing reef of the island, at a concentration of 0.74 pieces $\mathrm{m}^{-2}$. Additionally, this study reports for the first time the ingestion of microplastic by the corallimorpha Discosoma nummiforme. Microplastics were made available to corallimorph polyps in a laboratory setting over the course of 108 hours. Positively and negatively buoyant microplastics were ingested, and a microplastic particle that was not experimentally introduced was also discovered in the stomach cavity of one organism. This study indicates that plastic pollution has the potential to negatively impact coral reef ecosystems of the South Pacific, and warrants further study to explore the broader potential impacts of plastic pollution on coral reef ecosystems. 
1 Distribution and biological implications of plastic pollution

2 on the fringing reef of Mo'orea, French Polynesia

3

4

5

6

7

8

9

10

11

12

13

14

15

16

17

18

19

20

21

22

23

24

25

26

27

28

29

30

31

32

33

34

35

36

37

38

39

40

41

42

43

44

45

46

Corresponding Author:

Elizabeth Connors ${ }^{1}$

Email address: bethconnors@berkeley.edu

Elizabeth Janice Connors ${ }^{1}$

${ }^{1}$ Marine Science and Integrative Biology, University of California, Berkeley, California, USA

Enail address:bethoonnors@berkeley.edu

17

(1)

(1)

3

5


47 Abstract. Coral reef ecosystems of the South Pacific are extremely vulnerable to plastic

48 pollution from oceanic gyres and land-based sources. To describe the extent and impact of

49 plastic pollution, the distribution of both macro- $(>5 \mathrm{~mm})$ and microplastic (plastic $<5 \mathrm{~mm})$ of the

50 fringing reef of an isolated South Pacific island, Mo'orea, French Polynesia was quantified.

51 Macroplastic was found on every beach on the island that was surveyed. The distribution of this

52 plastic was categorized by site type and by the presence of Turbinaria ornata, a common

53 macroalgae on Mo'orea. Microplastics were discovered in the water column of the fringing reef of the island, at a concentration of 0.74 pieces $\mathrm{m}^{-2}$. Additionally, this study reports for the first time the ingestion of microplastic by the corallimorpha Discosoma nummiforme. Microplastics were made available to corallimorph polyps in a laboratory setting over the course of 108 hours. Positively and negatively buoyant microplastics were ingested, and a microplastic particle that was not experimentally introduced was also discovered in the stomach cavity of one organism. This study indicates that plastic pollution has the potential to negatively impact coral reef ecosystems of the South Pacific, and warrants further study to explore the broader potential impacts of plastic pollution on coral reef ecosystems.

Introduction. Anthropogenic debris is accumulating at a rapid rate in coastal and oceanic ecosystems worldwide (Critchell \& Lambrechts, 2016). The most significant contributor to these growing marine litter deposits is plastic (Islam \& Tanaka, 2002), a material widely used by humans (Ericksen et al., 2013). In the marine environment, plastic is initially buoyant, and easily dispersed over long distances via wave action and wind (Derraik, 2002). Floating plastic is detrimental to both ecosystem nutrient cycling and marine wildlife, as it can absorb and secrete chemicals (Moore et al., 2001; Islam \& Tanaka, 2002). Larger plastic pieces (macroplastic $>5 \mathrm{~mm}$ ) are degraded by UV light and wave action into microplastics $(<5 \mathrm{~mm})$ (Gregory 1999, Eriksen et al., 2013). Plastic pollution, especially microplastic, is often confused for food by marine organisms (Avio, Gorbi \& Regoli, 2016), and absorbed toxins in plastic pollution can bioaccumulate in higher trophic levels (Rochman et al., 2013; Farrell \& Nelson, 2013). High concentrations of floating plastic debris have been reported in many areas of the ocean (Cózar et al., 2014), in particular at the center of oceanic gyres (i.e., the great "garbage patches" (Berloff \& McWilliams, 2002)). The South Pacific gyre is dominated by microplastic particles (plastic $<5 \mathrm{~mm}$ in diameter) (Eriksen et al., 2013).

The islands of the South Pacific are sinks and sources for plastic in the marine ecosystem. Uninhabited islands in the area accumulate plastic debris at alarming rates, acting as sinks for plastic from the South Pacific gyre (Lavers \& Bond, 2017). Most of the inhabited islands in this region are also a source of plastic entering the marine environment, as their landfills are generally uncontrolled tipping locations on or near the coast (Morrison \& Monroe, 1999; Hayes $\&$ Richards, 2010). In French Polynesia, which has the most technologically advanced waste management center of the whole Pacific region, it is unclear if the amount of plastic pollution entering the marine environment has increased as funding for their landfill has shifted from the French government to local municipalities since 2010 (Morrison and Monroe, 1999; Hayes and Richards, 2010).

Coral reefs, a common coastal ecosystem of South Pacific Islands, are productive and biologically diverse (Mumby et al., 2015; Trapon et al., 2010). Although coral reefs cover $0.2 \%$ of the ocean floor, they contain around one third of all described marine species (Reaka-Kudla, 1997), and millions of people in the South Pacific depend on coral reefs for food (Costanza et al., 1997). Coral reefs are threatened by anthropological effects on a local and global scale, including 
93

94

95

96

97

98

99

100

101

102

103

104

105

106

107

108

109

110

111

112

113

114

115

116

117

118

119

120

121

122

123

124

125

126

127

128

129

130

131

132

133

134

135

136

137

138 sedimentation, increasing temperatures from global climate change, and changes in sea water chemistry (Wilkinson, 1999; Fitt, 2001; Hoegh-Gulberg et al., 2007). Macroplastics such as fishing nets are known source of coral degradation (Donohue et al., 2001), and microplastics contaminate the reefs around Australia, including the Great Barrier Reef (Reisser et al., 2013; Hall et al., 2014). It is unclear how the magnitude of plastic pollution on the fringing reef of a South Pacific Island would compare to Australian coastal waters.

Our knowledge of the biological impact of plastic pollution on coral is limited. The ingestion of microplastic by scleractinian (reef-building) corals has been observed in a laboratory setting (Hall et al., 2014), but never in situ. The ingestion of plastic by a large-bodied, noncalcifying coral (Lin et al., 2016; Kuguru et al., 2007), Discosoma nummiforme was examined in this study. Corallimorphians including D.nummiforme are more resilient to temperature and rising $\mathrm{CO}_{2}$ levels than scleractinian corals (Medina, 2006; Kuguru et al., 2007; Norstrom et al., 2009; Vernon et al., 2009), and may ingest plastic particles at a slower rate than scleractinian corals.

Categorizing the distribution of plastic pollution on the South Pacific island of Mo'orea, French Polynesia, as well as understanding the interaction between plastic pollution and resilient corals like corallimorphs will help us understand the magnitude of the threat that plastic pollution poses to coral reef ecosystems in the South Pacific region. This work specifically aimed to (1) understand the extent of the current macroplastic pollution problem on the South Pacific island of Mo'orea, French Polynesia (2) determine the concentration of microplastic particles in the water column of the fringing reef of Mo'orea and (3) evaluate if plastic particles are ingested by the corallimorph Discosoma nummiforme.

\section{Methods.}

\section{Island-wide field survey of macroplastic}

Mo'orea (17 30' S, 149 50' W), French Polynesia, has a fringing coral reef that encircles the whole island (Fig 1). The three main populated centers on the island are Afareaitu (2012 census pop. 3,455), Haapiti (pop. 4,062) and Pao Pao (population 4,580) (Brinkhoff, 2012; see Fig 1). Plastic surveys were conducted over the course of six weeks, from October 10 to November 20 2016, on beaches around Mo'orea (Fig 1). Additional plastic sampling was conducted at the two largest public beaches on the island: Plage Public de Ta'ahiamanu (17 29'32.7'S 149 51'00.8' W), and Temae Beach (17 29'54.5'S, 149 45'42.9'W), The laboratory study was also conducted on the island, at the Richard B. Gump Research Station (17 29'25.1” S 149 49'35.5” W, Fig 1).

Macroplastic (plastic $>5 \mathrm{~mm}$ ) abundance was surveyed on Mo'orea's perimeter road kilometer markers (called PK markers) (Fig 1). On the northern side of the island, the waterfront (typically beaches or river outlets) at every PK marker of the perimeter road were surveyed, and around the remainder of the island, the beaches were surveyed at every $3^{\text {rd }}$ PK marker, due to accessibility issues (the waterfront was not accessible from the road at every PK marker, especially on the southern side and northeastern corner of the island). The PK markers were used to randomize the types and location of sites categorized. Upon reaching a site at the PK marker, the site was first categorized by anthropogenic "site type": residential, hotel, natural or public beach site. (Of the 26 sites visited, ten were classified as residential sites, four as hotels, four as public beaches and eight as natural sites, see Fig 2) The presence or absence of the abundant macro algae Turbinaria 
139 ornata was then recoded. This macroalgae was recorded in the study because pilot data indicated 140 that this algae forms mats on the surface of the water, in which plastic is often entangled. The 141 residential and natural beaches were categorized as either non-T. ornata or T. ornata beaches,

142 but the five river outlet sites and the four hotel sites surveyed were counted as separate categories

143 in this analysis, as water movement in river outlets and hotel clean-up efforts affected T. ornata

144 presence at these sites. Once the beach was categorized by anthropogenic site type and

145 presence/absence of $T$. ornata, a timed five-minute trash pickup was conducted. Two

146 researchers, beginning at exactly the PK marker, walked along the beach in opposite directions,

147 collecting all plastic pieces within 5 meters of shore, for the survey. At each site, after the

148 number of plastic particles collected on the beach in the interval was recorded, the percent of

149 plastic of the total pollution found at the site was estimated. Percent plastic of all pollution and

150 total number of plastic pieces collected in the surveys were quantified separately because they

151 were not correlated (linear regression $\mathrm{p}>0.5$ ). Additionally, the distance in $\mathrm{km}$ between the

152 nearest population center (Afareaitu, Haapiti, or Pao Pao, depending on which was closest to the

153 site) and the beach site was recorded.

154

155

156

157

\section{Microplastic survey}

A plankton net (mouth size $0.07 \mathrm{~m}^{2}$; mesh size $0.05 \mathrm{~mm}$ ) was used to collect water samples at Plage Publique de Ta'ahiamanu, to test for the presence of microplastic in the water column. A total of six 3-meter plankton tows were conducted at the surface of the water in the intertidal zone of the beach, at randomly chosen intervals (of approximately $5 \mathrm{~m}$ ) parallel to shore. The total area of water surveyed was calculated using the formula: $\mathrm{A}=1 * \mathrm{w}$, where 1 is the diameter of the net $(0.3 \mathrm{~m})$ and $\mathrm{h}$ is 18 meters ( $3 \mathrm{~m} \mathrm{x} 6$ trials). The area of the water surface, as opposed to a volume of ocean water, was calculated to homogenize the results with similar studies on coastal plastic. Microplastics were identified under a light microscope at the Gump Research Station. Each piece discovered was measured and photographed, and the number of plastics was divided by the surveyed area to determine microplastic concentration.

\section{Corallimorph plastic ingestion experiment}

The plastic used in the study was collected from Temae beach sand (Fig 1) and isolated from the bath product "LAINO Exfoliating shower gel". The naturally collected plastic found in the sand was used in the study because of its negative buoyancy; $5 \mathrm{~mm}$ pieces of plastic were taken to Gump Station, and smashed with a hammer until they matched the size of observable microplastic in the water column $(0.2-1 \mathrm{~mm}$ diameter). The polyethelene plastic beads in the shower gel were isolated by water filtration in a $0.005 \mathrm{~mm}$ plankton sieve. All of the isolated beads were a uniform size of $0.2 \mathrm{~mm}$, green in color, and positively buoyant. Plastic color was used to differentiate the buoyancy of the plastic, as the positively buoyant plastic beads from the shower gel were green, while the negatively buoyant plastic collected at Temae were blue.

A total of 44 corallimorph polyps were collected from the fringing reef in a depth range of 1-3 m of water at Plage Publique de Ta'ahiamanu (Fig 1) Corallimorphs were identified to a species level following the descriptions of Fautin and the Mo'orea Biocode database as Discosoma nummiforme (Paulay, 2007; Fautin, 2012). The disconnected polyps (average diameter 5mm) remained attached to coral rubble rocks for the duration of the experiment. At the Gump Station, 
185 the polyps were given one week to adjust to laboratory conditions in a large flow $\operatorname{tank}\left(28^{\circ} \mathrm{C}\right.$ 186 unfiltered ocean water), then thirty-four were placed in a separate experimental tank $(28 \mathrm{~cm} * 30$ $\mathrm{cm} * 8 \mathrm{~cm})$ where they were exposed to plastic. Ten organisms were maintained as control.

In the experimental tank, $0.5 \mathrm{~mL}$ of both the lab-isolated and of the naturally collected plastic ( $1 \mathrm{~mL}$ total plastic) haphazardly placed on and around the corallimorph polyps. The water flow in the tank containing the corallimorphs was stopped during this procedure. Flow reduction of and the high plasitc concentration were used to ensure the most ideal conditions for plastic consumption. After $84(\mathrm{n}=19)$ or $108(\mathrm{n}=15)$ hours, the polyps were dissected, and number and color of plastic present in the organisms' tissues were recorded.

\section{Statistical Analysis}

Non-parametric tests were used as the number of samples per site type were not equal. Differences in amount of macroplastic present on beaches among the different beach classifications were examined for significance using a Kruskal-Wallace test, and a post-hoc Kruskal-Nemenyi test. To test for differences in macroplastic abundance in the presence of Turbinaria, a Kruskal-Wallace test was used. To test if distance from population centers on the island was predictive of macroplastic concentrations on sampled beaches a linear regression was used. For the microplastic feeding trial data, a Wilcoxon Rank Sum Test was used to examine the significance of the differences in natural-caught negatively buoyant plastic vs isolated, buoyant plastic over the time periods. This test was also used to examine the significance of the different hourly rates of consumption. All statistical tests were conducted in R (R Core Team, 2016).

\section{Results.}

\section{Island-wide field survey of macroplastic}

Plastic was found on every beach surveyed on the island. Other than plastic, the most common pollutants were glass, metal and cloth. Public beaches, natural areas and residential areas had similar amounts of plastic $(45 \pm 5 \mathrm{SD})$. These three site types had ten times higher levels of average number of plastic pieces than hotel beaches $(4.75 \pm 1 \mathrm{SD})$. The differences of means in plastic amount collected varied by site type (Kruskal-Wallace, Chi-sq $=9.6,3 \mathrm{df}, \mathrm{p}<0.05$, Fig 2a). In the post-hoc analysis, the mean of plastic collection on hotel beaches was lower than natural and public sites $(\mathrm{p} \leq 0.05)$, but the mean amount of plastic collected on hotel beaches was not significantly lower than residential beaches (Posthoc Kruskal-Nemenyi, $p>0.1$ ). Of the 26 sites, 17 were natural beaches, of which 7 had Turbinaria, and 10 had no Turbinaria. $29 \%$ more plastic was present on beaches that had Turbinaria present than on clean beaches. (Posthoc Kruskal-Nemenyi test, $\mathrm{p}<0.05$ ) When compared to the remaining sites (river outlets and hotel beaches), mean plastic amount was higher on beaches with Turbinaria present. (KruskalWallace, Chi-sq $=15.0,3 \mathrm{df}, \mathrm{p}<0.01$, Fig $2 \mathrm{~b}$ ). The percentage of plastic on the beaches ranged from $20 \%$ to $100 \%$ of the total pollution present, with an average of $68 \%$ plastic pollution. The number of plastic pieces, as well as the percentage of plastic of all waste found on the beaches, increased with distance from population centers, but not significantly (linear regression for both, $p>0.05$, Fig 3). 
231

232

233

234

235

236

237

238

239

240

241

242

243

244

245

246

247

248

249

250

251

252

253

254

255

256

257

258

259

260

261

262

263

264

265

266

267

268

269

270

271

272

273

274

275

\section{Microplastic concentration}

Microplastic was found in the water column at the collection site, with a total of four pieces found in the six tows. One of the four small pieces of plastic was assumed to be, based on color and texture, from a larger piece of plastic collected in the tow. Overall, the six tows contained 0.74 pieces of microplastic $\mathrm{m}^{-2}$ surface area.

\section{Exposing corallimorphs to microplastic}

Of the 34 corallimorph polyps exposed to plastic, 19 (55\%) polyps ingested one or more plastic particles during the experiment. The number of plastic particles ingested by individual polyps varied from zero to eight. The average amount of plastic consumed in the shorter time trial was 0.7 pieces/polyp and in the longer time trial 1.5 pieces/polyp. The mean amount of total plastic ingested did not vary with treatment time (Wilcoxon rank sum test, $p>0.05$, Fig 4). Although the total amount of plastic did not vary over the treatments, the amount of the positively buoyant plastic (the green micro-bead plastic) consumed increased over the separate time trials. In the first treatment time of 84 hours, an average of 0.7 blue plastic particles (BPP)/polyp were consumed by the corallimorphs and 0 green plastic particles (GPP)/polyp were consumed. In the longer trial of 108 hours, an average of $0.9 \mathrm{BPP} /$ polyp and $0.5 \mathrm{GPP} /$ polyp were consumed. The GPP consumed varied significantly over the separate time trials. (Wilcox rank sum test, $\mathrm{p}<0.01$, see Fig 4). Additionally, a yellow plastic particle was found in a polyp in the first treatment, presumably present in the tissue before the experiment. (see Fig 4) The ten control corallimorph polyps consumed zero plastic particles, experimentally introduced or otherwise.

\section{Discussion.}

Plastic accumulated most on natural beaches, and the amount of plastic and percentage of plastic debris increased insignificantly with distance from major population centers. This distribution of plastic on the island is somewhat surprising when compared to the literature, which generally find larger litter loads near urban areas (Garrity \& Levings, 1993; Ryan et al., 2009). While natural areas had a higher than expected amount of plastic, the large volume of plastic on the public beaches of Mo'orea supports previous literature on coastal plastic debris. A recent review article on coastal pollution categorized over $60 \%$ of coastal pollution as from sources of "shoreline and recreational activities" that are prevalent on public beaches (Vennila, Jayasiri \& Pandey, 2014). Finally, little scientific literature exists on hotel management of plastic debris, but the low amount of plastic discovered on hotel beaches is likely explained by hotel staff working to maintain a clean, white and sandy beach, as expected by hotel guests (Mo'orea Hilton manager, personal comm).

The beaches contaminated with Turbinaria ornata had a significantly higher amount of plastic than beaches without it. In the study, the plastic pieces collected were often caught in the thallus of this algae. The comingling of marine organisms and plastic is not a new phenomenon, as invertebrates and algae have been associated with plastic (Whitacre, 2012). Retention of plastic by $T$. ornata mats floating at the water's surface may in fact account for the low presence of plastic found on beaches near population centers, as floating T. ornata mats can travel long distances (Martinez, 2007), and the currents of Mo'orea change rapidly (Hench, Leichter \& 
276 Monismith, 2008). Further investigation into the association between plastic pollution and $T$.

277

278

279

280

281

282

283

284

285

286

287

288

289

290

291

292

293

294

295

296

297

298

299

300

301

302

303

304

305

306

307

308

309

310

311

312

313

314

315

316

317

318

319

320

ornata is necessary to fully understand their association.

Surface waters of the intertidal zone of Mo'orea are contaminated with small plastics. This study adds to the evidence in the literature that suggests microplastics are the most abundant type of debris in all marine environments (UNEP, 2016). The concentrations of microplastic is much higher in oceanic gyres than it is on Mo'orea; as high as 334 pieces $\mathrm{m}^{-2}$ in the Northeast Pacific (Moore et al., 2001), and 396 pieces $\mathrm{m}^{-2}$ in the center of the South Pacific gyre (Eriksen et al., 2013). The concentration of plastic found in Mo'orea's intertidal zone, however, is on the same order of magnitude as studies conducted outside of oceanic gyres of different geographic areas. For instance, the concentration in the Caribbean Sea $\left(1.414\right.$ pieces $\left.\mathrm{m}^{-2}\right)$, and the concentration in the Gulf of Maine (1.534 pieces $\mathrm{m}^{-2}$ ) are both are slightly higher, but of a consistent magnitude when compared to the found concentration of 0.74 pieces $\mathrm{m}^{-2}$ in Mo'orea (Law et al., 2010). This equivalent magnitude of plastic on Mo'orea and the North America and Carribean coast is unexpected, as the concentration of plastic off the coast of a highly developed area should have a higher magnitude of plastic than an island in the South Pacific. Off the coast of Australia researchers found that plastic accumulates in waters near population centers (Reisser et al., 2013). Papeete, the capital of neighboring island Tahiti, is a relatively densely populated city, and likely has a large amount of plastic use, that may contribute to the plastic on Mo'orea. Any future study of the intertidal zone should include a larger portion of Mo'orea's and even Tahiti's coastline, covering $\mathrm{km}$ rather than meters of water, to further investigate microplastic accumulation in the region.

This study demonstrated, for the first time, the ingestion of microplastic by the corallimorphia $D$. nummiforme. The corallimorph polyps in the study ingested plastic particles at a slower rate than the scleractinian coral from Hall et al.'s 2014 paper (55\% polyps inundated in 108 hours, versus $21 \%$ polpys in 12 hours; Hall, 2014). Although plastic consumption occurred at a slower rate, plastic presence in both studies caused considerable mucus formation that may represent an additional energy expense associated with microplastic contamination (personal observation; Hall et al., 2014). In both studies, plastic particles were found within the mesenterial tissue upon dissection, which may impede the digestion of these organisms (Hall et al., 2014).

In the experiment, the negatively buoyant plastic was ingested more often by these benthic organisms. The ingestion of the positively buoyant plastic by the corallimorph polyps is more surprising, especially because it only occurred in the longer treatment time (108 hours). It has been previously hypothesized that corallimorphs prey on zooplankton or absorb dissolved organic material at an increased rate to survive temperature changes (Kuguru et al., 2007), so it is possible that under the induced stressful conditions (no water flow), the polyps altered their feeding rate and consumed more plastic. It is also possible that the green microbeads began to sink over time, and as they entered the benthic environment the polyps consumed them as apparent food. The high concentration of plastic and low flow in the experiment were ideal conditions for plastic consumption; future studies more similar to the actual reef environment are necessary for predicting rates of plastic consumption by corallimorphs in situ. These studies are essential especially because in this study, the presence of yellow plastic in the stomach cavity of D. nummiforme demonstrates that plastic is being ingested by corallimorphs on the reef of Mo'orea. 
321

322

323

324

325

326

327

328

329

330

331

332

333

334

335

336

337

338

339

340

341

342

343

344

345

346

347

348

349

350

351

352

353

354

355

356

357

358

359

360

361

362

363

364

In conclusion, plastic pollution is prevalent on the beaches and reef of Mo'orea, as it was found on every beach visited during the study. Macroplastic was found in significant higher amounts on beaches with the algae T. ornata, and future study is warranted to understand if plastic pollution is transported around the island by this alga. Microplastic pollution was found in the water column of the fringing reef, and in the stomach tissue of the prevalent reef organism D.nummiforme. Under laboratory conditions, both buoyant and non-buoyant plastic were ingested by this corallimorphia. Further study into the distribution and biological consequences of plastic pollution on Mo'orea, and neighboring islands, is necessary to understand and combat this ongoing problem.

Acknowledgments. The author thanks Dr. Jonathon Stillman, Dr. Justin Brashares, Dr. Cindy Looy, Dr. Patrick O'Grady (UC Berkeley) and three anonymous reviewers for their valuable comments on the manuscript; Mr. Eric Armstrong, Mr. Ignacio Escalante Meza, Dr. Natalie Stauffer-Olsen and the Gump Station staff for their assistance with field logistics; and Mr. Eric Witte, Ms. Charlotte Runzel and Ms. Jacey Van Wert for the assistance sampling corallimorphs.

\section{References}

Anthony KRN. 2016. Coral reefs under climate change and ocean acidification: challenges and pportunities for management and policy. Annual Review of Environmental Resources. 41:59-81.

Avio CG, Gorbi S, Regoli F. 2016. Plastics and microplastics in the oceans: from emerging pollutants to emerged threat. Marine Environmental Research. 1:1-10 DOI:

http://dx.doi.org/10.1016/j.marenvres.2016.05.012.

Berloff P, McWilliams J. 2002. Material transport in oceanic gyres. American Meteorological

Society. DOI: http://dx.doi.org/10.1175/1520-0485(2002)032<0797:MTIOGP>2.0.CO;2.

Brinkhoff T. 2012. French Polynesia: cities and town populations from the 2012 census.

Available at https://www.citypopulation.de/FrPolynesia.html (accessed 15 March 2017).

Costanza R, D'arge R, Degroot R, Farber S, Grasso M, Hannon B, Limburg K, Naeem S, O’Neill RV, Paruelo J, Raskin RG, Sutton P, Van den belt M. 1997. The value of the world's ecosystem services and natural capital. Nature. 387:253-260.

Cózar A, Echvarria F, González-Gordillo JI, Irigoien X, Ubeda B, Hernández-León S, Palma AT, Navarro S, García-de-Lomas J, Ruiz A, Fernández-de-Puelles ML, Duarte CM. 2014. Plastic debris in the open ocean. Proceedings of the National Academy of Sciences. 28:102391244.

Critchell K, Lambrechts J. 2016. Modelling accumulation of marine plastics in the coastal zone; what are the dominant physical processes? Estuarine Coastal and Shelf Science 171:111-112. DOI: $10.1016 / j . e c s s .2016 .01 .036$. 
365 Derriak J. 2002. Pollution of the marine environment by plastic debris: a review. Marine

366 Pollution Bulletin. 44:842-852.

367

368 Donohue MJ, Boland RC, Sramek CM, Antonelis GA. 2001. Derelict fishing gear in the

369 northwestern Hawaiian Islands: diving surveys and debris removal in 1999 confirm threat to

370 coral reef ecosystems. Marine Pollution Bulletin. 42:1301-1312.

371

372 Eriksen M, Maximenko N, Thiel M, Cummins A, Lattin G, Wilson S, Hafner J, Zellers A,

373 Rifman S. 2013. Plastic pollution in the South Pacific subtropical gyre. Marine Pollution

374 Bulletin. 68:71-76.

375

376 Eriksen M, Lebreton LCM, Carson HS, Thiel M, Moore CJ, Borerro JC, Galgani F, Ryan PG,

377 Reisser J. 2014. Plastic pollution in the world's oceans: more than 5 trillion plastic pieces

378 weighing over 250,000 tons afloat at sea. PLoS ONE. 9:12: e111913.

379 DOI:10.1371/journal.pone.0111913.

380

381 Farrel P, Nelson K. 2013. Trophic level transfer of microplastic: Mytilus edulis to Carcinus

382 maenas. Environmental Pollution. 177:1-3.

383

384 Fautin, D. 2012. Discosoma nummiforme: a hexacorallians of the world: World Register of

385 Marine Species. Available at http://www. marinespecies.org/aphia.php? $p=$ taxdetails\&id=411031

386 (accessed 2 October 2016).

387

388

Fitt W, Brown BE, Warner ME, Dunne RP. 2001. Coral bleaching: interpretation of thermal

389 tolerance limits and thermal thresholds in tropical corals. Coral Reefs. 20:51-65.

390

391

392

Garrity SD, Levings SC. 1993. Marine debris along the Caribbean coast of Panama. Marine

393

394 Gregory, M. 1999. Plastic and South Pacific Island shores: environmental implications. Ocean

395 and Coastal Management. 42:603-615.

396

397 Hall NM, Berry KLE, Rintoul L, Hoogenboom MO. 2014. Microplastic ingestion by

398 scleractinian corals. Journal of Marine Biology. DOI: 10.1007/s00227-015-2619-7.

399

400 Hayes E, Richards D. 2010. Solid waste management in Pacific island countries and territories. 401 Singapore: Springer Singapore.

402

403 Hench J, Leichter JJ, Monismith SG. 2008. Episodic circulation in a wave-driven coral reef and 404 lagoon system. American Society of Limnology and Oceanography. 53:2681-2694. 
406 Hoegh-Guldberg O, Mumby PJ, Hooten AJ, Steneck RS, Greenfield P, Gomez E, Harvell CD, 407 Sale PF, Edwards AJ, Caldeira K, Knowlton N, Eakin CM, Iglesias-Prieto R, Muthiga N, 408 Bradbury RH, Dubi A, Hatziolos ME. 2007. Coral reefs under rapid climate change and ocean 409 acidification. Science. 318:1737-1742.

410

411 Islam S, Tanaka M. 2004. Impacts of pollution on coastal and marine ecosystems including 412 coastal and marine fisheries and approach for management: a review and synthesis. Marine 413 Pollution Bulletin. 48:624-649.

414

415 Kuguru B, Winters G, Beer S, Santos, SR, Chadwick NE. 2007. Adaptation strategies of the 416 corallimorpharian Rhodactis rhodostoma to irradiance and temperature. Marine Biology.

417 151:1287-1298. DOI: 10.1007/s00227-006-0589-5

418

419

420

421

422

Law KL, Ferguson SM, Maximenko NA, Proskurowski G, Peacock EE, Hafner J, Reddy CM. 2010. Plastic accumulation in the North Atlantic subtropical gyre. Science. 329:1185-1188.

423

424

425

426

427

428

429

430

Lavers JL, Bond AL. 2017. Exceptional and rapid accumulation of anthropogenic debris on one of the world's most remote and pristine islands. Proceedings of the National Academy of Sciences. 114:6052-6055.

Lin MF, Chou WH, Kitahara MV, Chen CLA, Miller, DJ, Forêt S. 2016. Corallimorpharians are not "naked corals": insights into relationships between Scleractinia and Corallimorpharia from phylogenomic analyses. PeerJ. DOI: 10.7717/peej.2463.

431

Martinez E, Maamaatuaiahutapu K, Payri C, Ganachaud A. 2007. Turbinaria ornata invasion in the Tuamotu Archipelago, French Polynesia: ocean drift connectivity. Coral Reefs. 26:79.

432

433

434 435

436

437 DOI:10.1007/s00338-006-0160-3.

Medina M. 2006. Naked corals: skeleton loss in Scleractinia. PNAS. 103:9096-9100.

Moore CJ, Moore SL, Leecaster MK, Weisberg SB. 2001. A comparison of plastic and plankton in the North Pacific central gyre. Marine Pollution Bulletin. 42:1297-1300.

438

439

Morin E, Gatti C, Bambridge T, Chinain M. 2016. Ciguatera fish poisoning: incidence, health 440 costs and risk perception on Moorea Island (Society archipelago, French Polynesia). Harmful 441 Algae. 60:1-10.

442

443 Morrison R, Munro A. 1999. Waste management in the small island

444 developing states of the South Pacific: an overview. Australian Journal of Environmental 445 Management. 6:232-246, DOI: 10.1080/14486563.1999.10648474.

446 
447 Mumby PJ, Steneck RS, Adjeroud M, Arnold S. 2016. High resilience masks underlying

448 sensitivity to algal phase shifts of Pacific coral reefs. Oikos, 125:644-655.

449 doi:10.1111/oik.02673

450

451

452

Norstrom AV, Nyström M, Lokrantz J, Folke C. 2009. Alterative states on coral reefs: beyond coral-macroalgal phase shifts. Marine Ecology Progress Series. 376:295-306, DOI:

$45310.3354 /$ meps07815.

454

455

Paulay, G. 2007. Discosoma: Moorea Biocode of UC Berkeley. Available at

456

http://biocodetest.berkeley.edu/cgi/biocode img query? enlarge $=4444+4444+0907+004$.

457 (accessed 5 September 2016).

458

459

R Core Team (2016). R: A language and environment for statistical computing. R Foundation for

460

Statistical Computing, Vienna, Austria. Available at https://www.R-project.org/.

461

462

Reaka-Kudla ML. 1997. Global biodiversity of coral reefs: a comparison with rainforests.

463

New York: Joseph Henry Press. ISBN: 0-309-52075-4.

464

465

Reisser J, Shaw J, Wilcox C, Hardesty BD, Proietti M, Thums M, Pattiaratchi C. 2013. Marine

466

plastic pollution in waters around Australia: characteristics, concentrations, and pathways. PLoS

467

ONE. DOI:10.1371/journal.pone.0080466.

468

469

Rochman C, Hoh E, Kurobe T, Teh SJ. 2013. Ingested plastic transfers hazardous chemicals to

470

471

472

fish and induces hepatic stress. Nature: Scientific Reports. 3:3263. DOI: 10.1038/srep03263.

473

Ryan P, Moore CJ, Franeker JA, Moloney CL. 2009. Monitoring the abundance of plastic debris

474

475

476 in the marine environment. Philosophical Transactions of the Royal Society B: Biological

Sciences. 364:1526.

477

Trapon M, Pratchett MS, Penin L. 2010. Comparative effects of different disturbances in coral

478

479

reef habitats in Mo'orea, French Polynesia. Journal of Marine Biology. 2011: 807625.

UNEP and GRID-Arendal. 2016. Marine Litter Vital Graphics of the United Nations

480

481

482

483

484

485

486 Veron JEN, Hoegh-Guldberg O, Lenton TM, Lough JM, Obura DO, Pearce-Kelly P, Sheppard

487

488

Environment Programme and GRID-Arendal. Available at www.unep.org (accessed 15

September 2016).

Vennila A, Jayasiri HB, Pandey PK. 2014. Plastic debris in the coastal and marine ecosystem: a menace that needs concerted efforts. IJFAS. 2:24-29. CRC, Spalding M, Stafford-Smith MG; Rogers, AD. 2009. The coral reef crisis: the critical importance of $<350$ ppm $\mathrm{CO}_{2}$. Marine Pollution Bulletin. 58:1429-1436

489 
490 Whitacre, D. 2012. Reviews of Environmental Toxicology. Springer. 220:31.

491

492 Wilkinson, CR. 1999. Global and local threats to coral reef functioning and existence: review 493 and predictions. Marine and Freshwater Research. 50:867-878.

494

495

496 
Figure 1

Location and study sites of Mo'orea Island

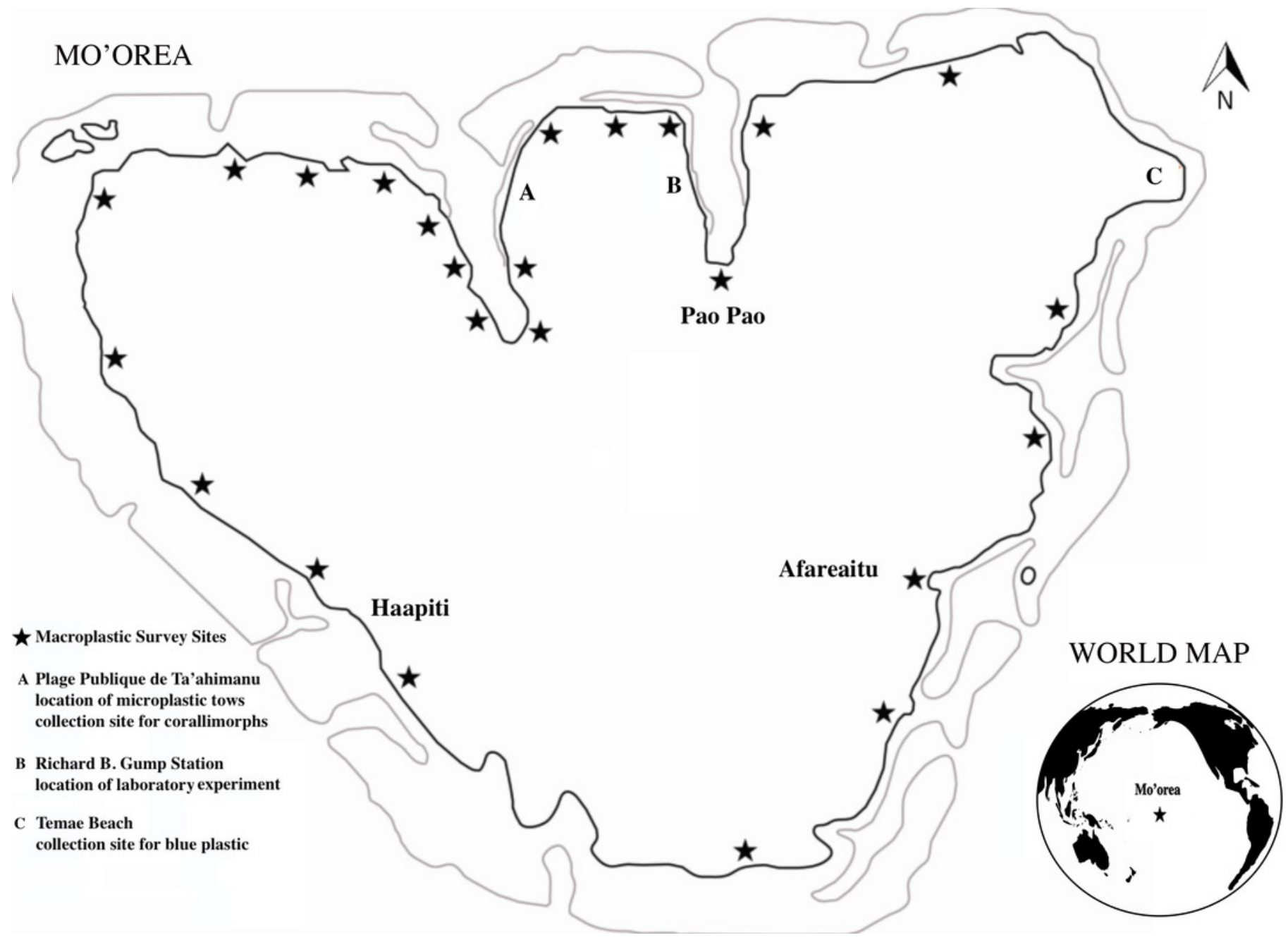


Figure 2

Number of macroplastic pieces collected in five-minute surveys, according to (A) site type and $(\mathrm{B})$ the presence of $\mathrm{T}$. oranata
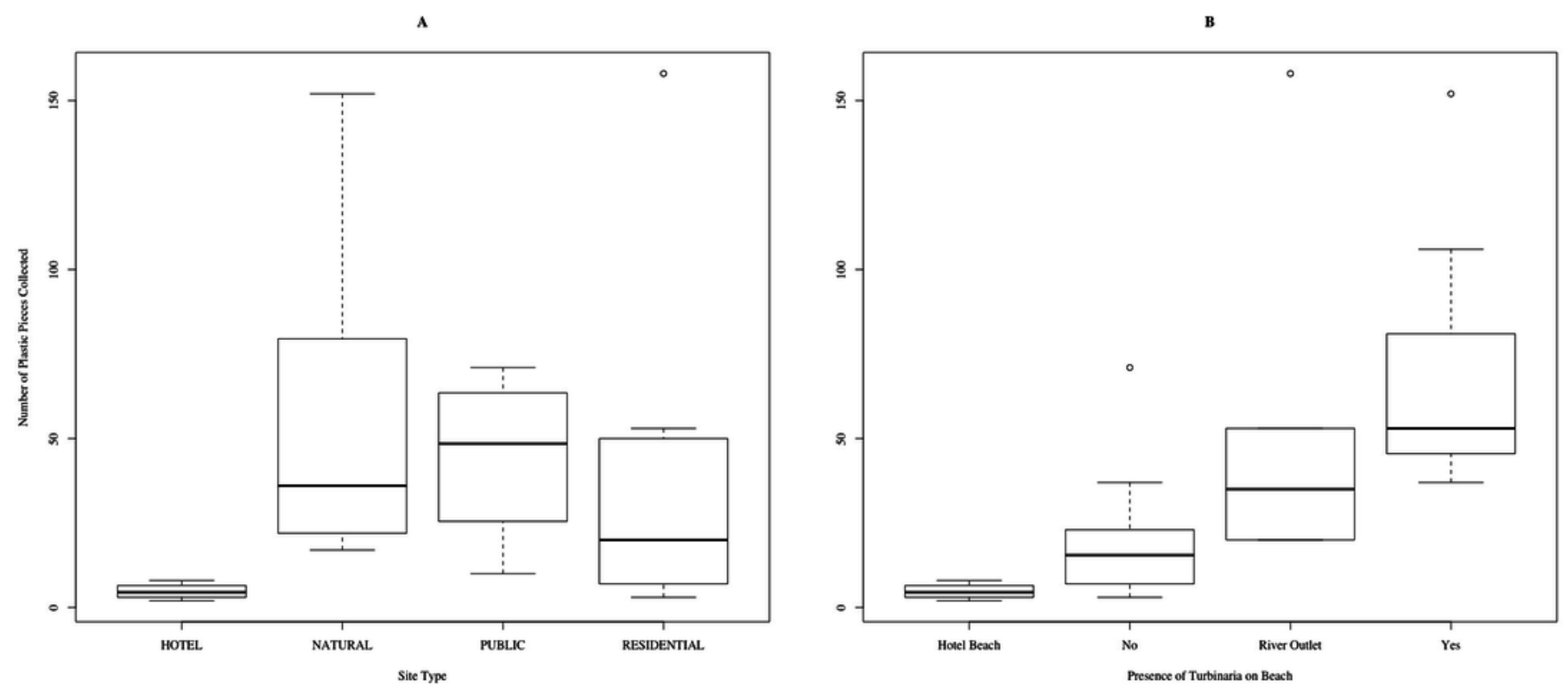
Figure 3

Linear regression between distance from population centers $(\mathrm{km})$ and both total plastic pieces collected in 5 minutes (grey triangles) and percentage of plastic of total trash found (black circles).

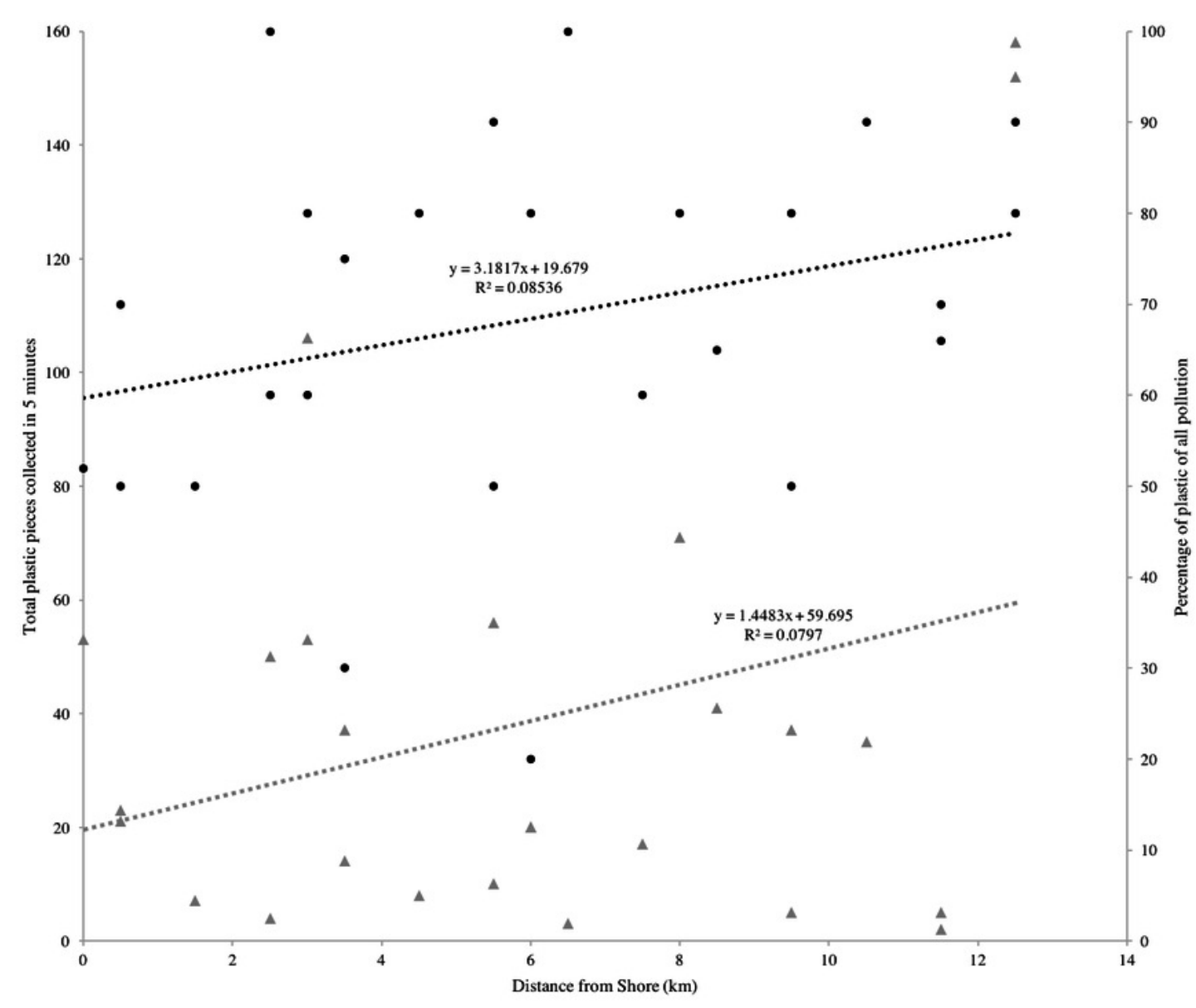

$\Delta$ Total Plastic

- Percent Plastic 


\section{Figure 4}

Number of plastic particles consumed by Discosoma nummiforme according to treatment time and plastic color

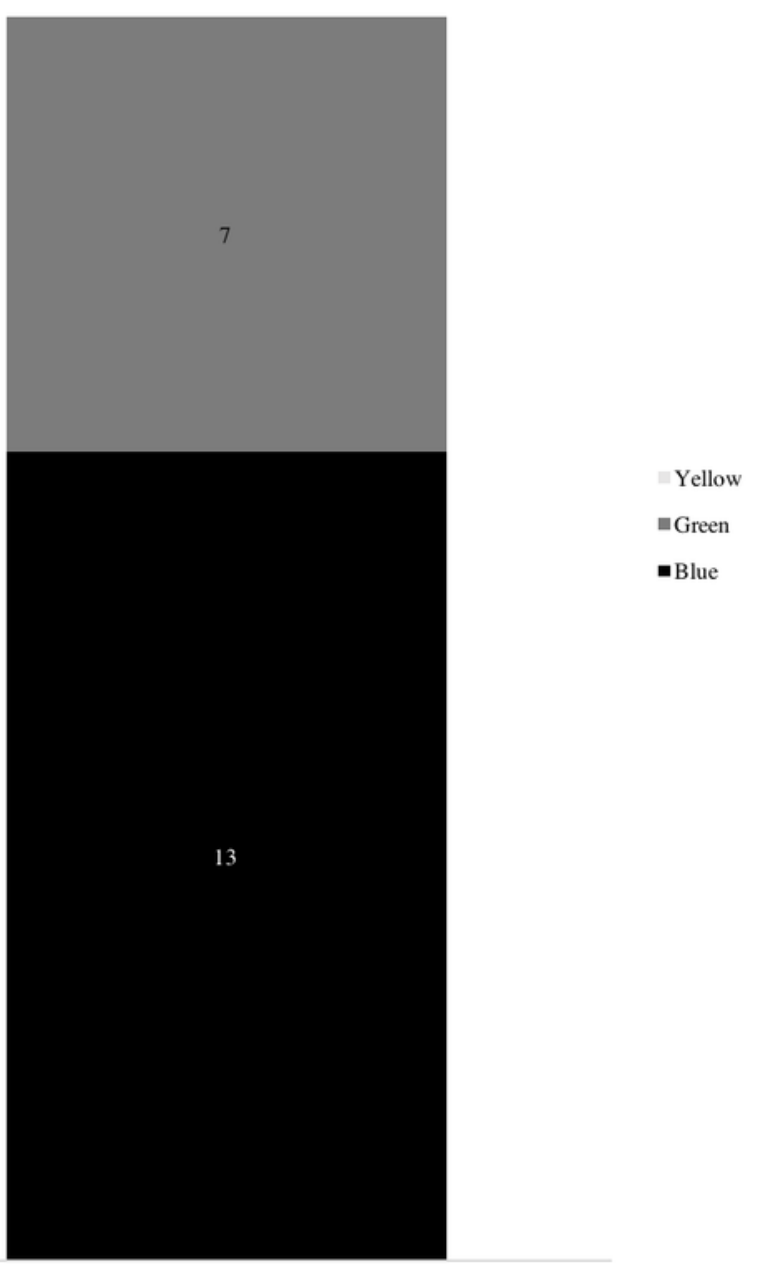

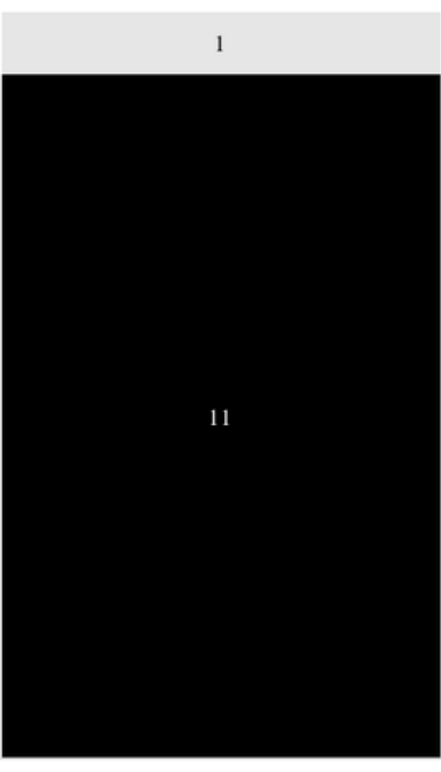

84 Hours

108 Hours 